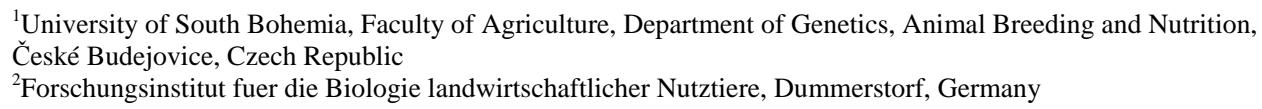

JINDRICH CITEK ${ }^{1}$, VACLAV REHOUT ${ }^{1}$, EVA HRADECKA ${ }^{1}$, LIBOR VECEREK $^{1}$ and LOTHAR PANICKE ${ }^{2}$

\title{
The Breeding Values of German Holstein Sires and the DGAT1 Polymorphism
}

\begin{abstract}
The effect of the genotypes and alleles at nucleotide positions 10433 and 10434 of the DGAT1 gene on the breeding values for milk performance of German Holstein sires born in 1993 ( $n=66)$, and in 1998-2001 ( $n=200)$ was analyzed. The differences in breeding values had in both years the same trend.

In the younger sires, the breeding value for fat percentage was higher by $0.42 \%$ in the Lysine homozygotes compared to the Alanine homozygotes $(P<0.001)$. A higher milk breeding value in the Alanine homozygotes (811 kg) was found compared to the Lysine homozygotes (256 kg) $(P<0.001)$, and the fat yield breeding value was higher in the Lysine sires (DGAT1 $\left.{ }^{K} / D G A T 1^{K} 29.6, D G A T 1^{A} / D G A T 1^{A} 15.9\right)$. The breeding value for the protein percentage was higher in the sires carrying the Lysine variant (0.02) than in the Alanine homozygotes ($0.03, P<0.05)$, and the protein yield was higher in the Alanine homozygotes $\left(D G A T 1^{K} / D G A T 1^{K} 10.9\right.$, $\left.D G A T 1^{A} / D G A T 1^{A} 25.0, P<0.001\right)$. Because of the high emphasis of the index on the protein yield, the relative breeding value for milk was 110 among Alanine homozygotes, and 104 among Lysine. Comparing old and young sires, the genetic background against which the effect of DGAT1 is evaluated has changed. The selection on breeding value for protein yield increased the prevalence of $D G A T 1^{A} / D G A T 1^{A}$ genotypes in protein and milk yield, and in relative breeding value for milk. In the old group, there was the highest protein yield in the heterozygous sires $D G A T^{K A}$, it could be explained by another genetic background of the tested female population. Because the breeding value for fat percentage of heterozygous sires has lain within the values of homozygotes in both old and young sires, we assume the intermediary heredity on the locus. The differences of genotypic and allelic frequencies among old and young sires were not significant, however, there was certain tendency of increase of allele A (0.60 old sires, 0.64 young). On the results of this paper, the locus of DGAT1 offers information for evaluation of breed animals.
\end{abstract}

Key Words: German Holstein; sires; breeding values; milk performance; DGAT1

\section{Zusammenfassung}

Titel der Arbeit: Zuchtwerte von schwarzbunten Bullen und DGAT1 Polymorphismus

In der Analyse wurde der Einfluss des K232A Polymorphismus des DGAT1 Genes auf die mittleren Zuchtwerte (ZW) für Milchleistung bei Deutschen Holstein Bullen untersucht. Die Bullen wurden in 1993 (n=66), und 19982001 ( $n=200)$ geboren. Die gesicherten Leistungsunterschiede der Genotypen folgen in beiden Bullengruppen der unterschiedlichen Jahrgänge einem einheitlichen Trend.

In der jüngeren Gruppe war der ZW für Fettgehalt bei Homozygoten mit Lysine Variante um 0,42\% höher, als bei den mit der Alanine Variante $(P<0,001)$, ZW für Milchleistung war bei Alanine Homozygoten $811 \mathrm{~kg}$, bei Lysine Homozygoten $256 \mathrm{~kg}(P<0,001)$. Davon ergab sich der höhere ZW für Fettproduktion bei Lysine Bullen $\left(D G A T 1^{K} / D G A T 1^{K} 29,6, D G A T 1^{A} / D G A T 1^{A} 15,9\right)$. ZW für Proteingehalt war höher bei Bullen die die Lysine Variante trugen $(0,02)$ als bei Alanine Homozygoten $(-0,03, P<0,05)$, Proteinproduktion war höher bei Alanine Homozygoten (DGAT1 $\left.1^{K} / D G A T 1^{K} 10,9, D G A T 1^{A} / D G A T 1^{A} 25,0, P<0,001\right)$. Als Folge des größeren Wertes der Proteinproduktion im Index Relativzuchtwert Milch war es bei Alanine Homozygoten 110, und 104 bei Lysine. Beim Vergleich von alten und jungen Bullen war eine gewisse Veränderung des genetischen Hintergundes erkennbar, an dem die Bewertung des DGAT1 genes stattfand. Durch die Selektion an ZW für Proteinproduktion wurde die Überlegenheit des $D G A T 1^{A} / D G A T 1^{A}$ Genotypes in Protein- und Milchproduktion und in Relativzuchtwert Milch betont. In der älteren Gruppe war die höchste Proteinproduktion bei Heterozygoten $D G A T^{K A}$, was auf den unterschiedlichen genetischen Hintergrund der Prüfpopulation zurückgeführt werden kann. Da der ZW für Fettgehalt von Heterozygoten sowohl bei alten als auch bei jungen Bullen zwischen beiden 
Homozygoten lag, ist die unvollständige Dominanz wahrscheinlich. Die Selektion an ZW für Proteinproduktion beeinflusste die allelischen und genotypischen Frequenzen nicht significant, obwohl eine geringe Zunahme des Allels $A$ von 0,60 bei den alten Bullen auf 0,64 bei den jungen Bullen vorliegt. Abschließend wird geschlußfolgert, dass der Lokus von DGAT1 eine zusätzliche Information für die Bewertung von Zuchttieren geben kann und damit Bedeutung für die Züchtung erlangt.

Schlüsselwörter: Deutsche Holsteins, Bullen, Zuchtwerte, Milchleistung, DGAT1

\section{Introduction}

Recently, marker assisted selection and genomanalyse are being focused on by investigators and breeders. The approach has great promise for economic important traits (XU et al., 2006; FREYER and VUKASINOVIC, 2005; FREYER et al., 2003; SCHWERIN, 2004; KALM, 1997), and usable results are available. The marker assisted selection has certain problems, because the family specific linkage must be found and moreover, not each marker is informative in the respective family. Therefore, also the coding genes should be studied with the aim of finding the locus for the early estimation of breeding value. Many polymorphous loci have been investigated; milk proteins, growth hormone or pituitary transcription factor should be mentioned (KUCEROVA et al., 2006; KOVACS et al., 2006; DYBUS et al., 2004). In recent years, DGAT1 diacylglycerol O - transferase has been found to be of great interest. It is a microsomal enzyme (EC 2.3.1.20) catalysing the final step of the triglycerid synthese, and it plays an important role in the metabolism of the cellular glycerolipid. The enzyme plays a part in the regulation of the concentration of triacylglycerol in plasma, fat tissue and cells, muscle metabolism, milk, egg, and oocytes in mammals. In the mouse, it maps to chromosome 15, in man to chromosome 8. The lack of DGAT1 in mice causes cachexy, and the loss of DGAT results in the loss of milk production due to insufficient synthese of triglycerids in the mammary gland. LUDWIG et al. (2002) report 5 polymorphisms in human DGAT1.

The bovine DGAT1 gene maps to the centromeric part of chromosome 14. Few polymorphisms were described in the locus; in the coding part of the gene the important one is in the amino acid position 232 Lysin - Alanin; the wild allele is lysine. At the DNA level it is caused by double substitution at the nucleotide position 10433 and 10434 in exon 8, AA instead of GC. In domesticated animals, the lysine variant positively influences the breeding value for fat content in milk (WINTER et al., 2002). According to SPELMAN et al. (2002), the polymorphism of DGAT1 in Jersey, Holstein-Friesian and Ayrshire in New Zealand, enhances the yield of milk fat, and reduces the yield of protein and milk. FRIES and THALER (2002) found a higher breeding value for fat production of the homozygous lysine genotype compared to the alanine, and vice versa for milk production. According to HARDER et al. (2006), the DGAT1 locus seems to be associated with fat yield throughout the whole lactation, and with milk yield and protein yield especially during the later stages of lactation. GRISART et al. (2004) expressing both DGAT1 alleles in Sf9 cells using the baculovirus expression system, confirmed the $D G A T 1^{K}$ allele as being characterized by higher triglyceride production than the $D G A T 1^{A}$. There is no single polymorphism in the respective chromosomal region; KÜHN et al. (2004) evidence the DGAT1 promoter polymorphism affecting the fat content; BENNEWITZ et al. (2004) presuppose an additional source of genetic variance on the bovine chromosome 14 and WINTER et al. (2004) mapped twenty-three genes neighboring DGAT1, and report the respective polymorphisms. WELLER et al. (2003) found the linkage 
disequilibrium between microsatellite ILSTSO39 and DGAT1. The DGAT1 ${ }^{K}$ allele, and microsatellite allele 225 were associated with lower milk production, and increased fat production and fat and protein content. The effects of two 225 alleles was approximately equal to twice the effect of a single allele. The linkage disequilibrium is population-wide, as one of the 225 alleles of these cows must have come from the cows' dams, and is not due to the specific linkage phase in heterozygous sires. This also indicates the additive effect of the DGAT1, even if they consider the next study of the additivity desirable.

\section{Material and methods}

The goal of the analysis was to evaluate the effect of the genotypes and alleles at nucleotide positions 10433 and 10434 of the DGAT1 gene on the breeding values of German Holstein sires. Two groups of German Holstein sires were genotyped, the 1st group were sires born in $1993(\mathrm{n}=66)$, the other, sires born in $1998-2001(\mathrm{n}=200)$. The actual breeding values estimated in 2006 (VIT Verden) have been assigned to the genotypes, and the associations were quantified.

DNA was isolated from whole blood following the method described in Gemmel, Akiyama (1996), the quick method of KAWASAKI (1990), or from frozen sperm following the method of ASHWELL et al. (1996). In cows, the proces could be potentially simplified by obtaining DNA from milk samples (BUITKAMP and GÖTZ, 2004). The respective part of the DGAT1 locus carrying the polymorphism studied was amplified in the polymerase chain reaction. The primer sequencies were as in WINTER et al. (2002), and the PCR was carried out on the Biometra T Gradient thermal cycler. The polymorphism K232A causing lysine to alanine substitution was distinguished by a restriction fragment length polymorphism using the restriction endonuclease CfrI (PCR/RFLP methods). The fragments were separated electrophoretically on agarose gel and stained with ethidium bromide. The restriction endonuclease $C$ frI splits the sequence Y/GGCCR ( $\mathrm{Y}$ is $\mathrm{C}$ or $\mathrm{T}, \mathrm{R}$ is $\mathrm{G}$ or $\mathrm{A}$ ). The $D G A T 1^{K}$ variante (Lysine) stays non split, while the variante $D G A T 1^{A}$ (Alanine) splits (Fig. 1).

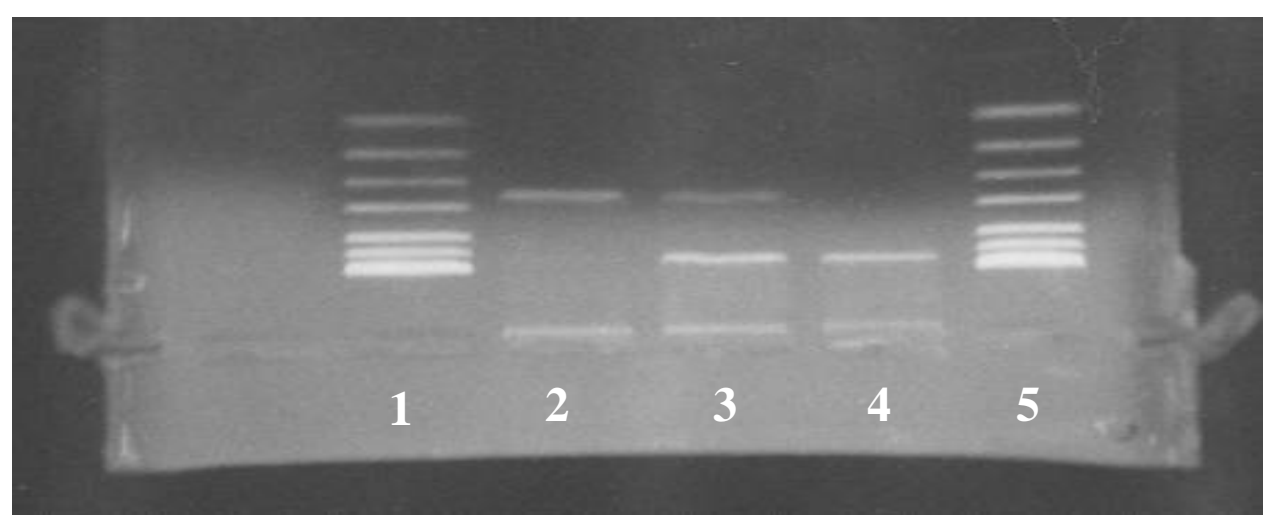

1. length marker, 2. genotype DGAT1 ${ }^{A} / D G A T 1^{A}$, 3. genotype $D G A T 1^{A} / D G A T 1^{K}$, 4. genotype DGAT1 $1^{K} / D G A T 1^{K}$, 5. length marker.

Fig. 1: PCR amplificate and restriction fragments of DGAT1 (PCR-Amplifikation und Restrictionsfragmente von DGAT1)

The German Holstein sires born in $1993(\mathrm{n}=66)$, and in 1998 - $2001(\mathrm{n}=200)$ were analysed. The Estimation of Breeding Values (EBV) for milk production traits (milk 
yield kg, fat percentage, fat yield kg, protein percentage, protein yield kg, and the relative breeding value for milk yield) by the Random Regression Model are described in the following. Intra-herd test day variance is standardised according to the production level on herd test day and the number of cows in the same lactation within the particular herd test day.

Breeding values of the first three lactations are estimated with the Random Regression Model:

$$
y_{i j k l o}=h_{i l}+\sum_{m=1}^{3} \beta_{j l m} f_{j l m}+\sum_{m=1}^{3} b_{k l m} a_{k l m}+\sum_{m=1}^{3} b_{k l m} p_{k l m}+e_{i j k l o}
$$

$y_{i j k l o}$ is a 24-hour test day yield, adjusted for heterogeneous herd variance of the $o$-th test day of lactation $l$ of cow $k$; $h_{i l}$ fixed effects of the $i$-th herd-test-date x milkingfrequency (HTD) for lactation $l ; f_{j l m}$ is the $m$-th regression coefficient for the $j$-th fixed lactation curve of lactation $l ; \beta_{j l m}$ is the $m$-th term of the Wilmink function; $a_{k l m}$ and $p_{k l m}$ are the $m$-th random regression coefficient of lactation $l$ of cow $k$ for genetic and permanent environmental effects; $b_{k l m}$ is the $m$-th term of the third-order Legendre polynomials; $e_{i j k l m o}$ the error effect.

The genetic parameters used in the Random Regression Model are estimated on the basis of a representative data set of the German Holstein population (LIU et al., 2000a, b). The breeding value on the lactation test-day base is the sum of the EBVs from day 1-305. The published breeding values are defined as the average breeding value of lactations one to three, and represent the desired breeding goal of high lifetime production. The Relative Breeding Value for Milk (RBVM) was also calculated: $\mathrm{RBVM}=93,9+0,140 * \mathrm{BV}$ fat $\mathrm{kg}+0,561 * \mathrm{BV}$ protein $\mathrm{kg}+5,047 * \mathrm{BV}$ protein \% (BV is breeding value, VIT Verden 2005/06). The "BV base 2000" recommended by Interbull is used to adjust the level of breeding values within the breed. This means that the average breeding value of all cows of the same breed born in 1995 is set to zero, and the breeding values of all animals are expressed in relation to their base.

The differences in breeding values according to DGAT1 genotype or allele were tested with analysis of variance separately for 1993 and 1998 - 2001 sires.

The analyses were performed with model equation

$y_{i j}=\mu+G_{j}+e_{i j}$

$y_{i j}$ is the breeding value of sire; $\mu$ is the overall mean; $G_{j}$ is the fixed effect of genotype / allele of DGAT; $e_{i j}$ is the residual effect.

The differences were evaluated at the significance levels of $P<0.05^{*}, P<0.01^{* *}$, and $P<0.001^{* * *}$. The software STATISTICA, (the ANOVA/MANOVA procedure) was used. The Hardy-Weinberg equilibrium was tested by the $\chi^{2}$ test, and the differences of frequencies between years were tested by the test of difference of relative frequencies.

\section{Results}

In sires born in 1998-2001, the breeding value for fat percentage was higher (over 0.42 $\%)$ in the DGAT1 ${ }^{K} / D G A T 1^{K}$ genotypes compared to the DGAT1 ${ }^{A} / D G A T 1^{A}(P<0.001)$. In contrast, there was found to be a higher milk breeding value in the Alanine homozygous genotype $(811 \mathrm{~kg})$ and Lysine/Alanine heterozygous genotype (498 kg) 
compared to the Lysine genotype (256 kg) (Table 1); the differences were significant at $P<0.001$. Similarly, the Alanine encoding allele produced a breeding value of milk yield, double that of the Lysine allele (Table 2). The higher percentage induced the higher breeding value for fat yield for $D G A T 1^{K} / D G A T 1^{K}$ sires, even though the milk yield was significantly lower. Also the breeding value for protein percentage was higher in the sires carrying the Lysine variante (0.02) than in the Alanine homozygotes $(-0.03)$, but the difference was not as high as in the fat percentage, and significant only at $P<0.05$. Therefore, the breeding value for protein yield in $\mathrm{kg}$ was higher in the Alanine homozygotes $(P<0.001)$ due to their distinctively higher breeding value for milk yield.

The Relative Breeding Value for Milk (RBVM) is the selection index; it has been defined as the comprehensive breeding value of milk performance indicators. RBVM involves the pedigree values for fat yield and protein yield in a 1:4 ratio, it also takes the breeding value for protein percentage into account. The relative breeding value for milk was 110 for $D G A T 1^{A} / D G A T 1^{A}$ sires, 107 for sires with $D G A T 1^{K} / D G A T 1^{A}$ genotype and 104 for $D G A T 1^{K} / D G A T 1^{K}$ genotype, apparently because of the emphasis of the index on the protein yield. Nevertheless, the factor genotype has not influenced the RBVM significantly (Table 1), while the difference between alleles, Lysine 106, and Alanine 109, was significant at $P<0.05$ (Table 2).

Table 1

Breeding values $\pm \mathrm{s}_{\mathrm{x}}$ of German Holstein sires born in 1998-2001 according to their genotype on the DGAT1 locus (Mittlere Zuchtwerte $\pm \mathrm{s}_{\mathrm{x}}$ von HF-Bullen des Geburtsjahrganges 1998-2001 in Abhängigkeit vom Genotyp am DGAT1 Lokus)

\begin{tabular}{|c|c|c|c|c|c|}
\hline & & \multicolumn{3}{|c|}{ Genotype } & \multirow{3}{*}{$F$} \\
\hline & & $D G A T 1^{K} / D G A T 1^{K}$ & $D G A T 1^{K} / D G A T 1^{A}$ & $D G A T 1^{A} / D G A T 1^{A}$ & \\
\hline & & $n=31$ & $n=84$ & $n=85$ & \\
\hline Milk & (kg) & $256^{\underline{A} \mathrm{a}} \pm 98$ & $498^{\underline{A} \mathrm{~b}} \pm 60$ & $811^{\underline{B}} \pm 59$ & $13.757^{* * *}$ \\
\hline $\mathrm{RBVM}^{+}$ & & $104^{\mathrm{a}} \pm 2$ & $107 \pm 1$ & $110^{\mathrm{b}} \pm 1$ & 2.988 \\
\hline Fat & (kg) & $29.6^{\mathrm{A}} \pm 3.9$ & $22.7^{\mathrm{a}} \pm 2.1$ & $15.9^{\mathrm{Bb}} \pm 2.3$ & $5.158^{* *}$ \\
\hline Protein & (kg) & $10.9^{\underline{A}} \pm 3.1$ & $17.3^{\mathrm{A}} \pm 1.9$ & $25.0^{\underline{B} \mathrm{~B}} \pm 1.9$ & $8.731^{* * *}$ \\
\hline Fat & $(\%)$ & $0.23^{\underline{A}} \pm 0.04$ & $0.03^{\underline{B}} \pm 0.02$ & $-0.19 \underline{C}_{ \pm 0.03}$ & $44.561^{* * *}$ \\
\hline Protein & (\%) & $0.02^{\mathrm{A}} \pm 0.02$ & $0.01^{\mathrm{a}} \pm 0.01$ & $-0.03^{\mathrm{Bb}} \pm 0.01$ & $4.279^{*}$ \\
\hline
\end{tabular}

${ }^{+} \mathrm{RBVM}=93,9+0,140 * \mathrm{BV}$ fat $\mathrm{kg}+$ 0,561*BV protein $\mathrm{kg}+5,047 * \mathrm{BV}$ protein \% (BV means breeding value, VIT Verden 2005/06).

** $\quad P<0.05 \quad$ a, b means with different letters differ significantly $(P<0.05)$

** $\quad P<0.01 \quad$ A, B means with different letters differ significantly $(P<0.01)$

*** $P<0.001 \quad \underline{A}, \underline{B}$ means with different letters differ significantly $(P<0.001)$

In sires born in 1993, the Alanine homozygotes were found to have the highest breeding value for milk yield of $588 \mathrm{~kg}$, as in the younger group (Table 3). Similarly, the fat and protein content in the 1993 group was highest in Lysine homozygous sires, while the Alanine/Alanine sires have significant negative breeding value. The effect of Alanine allele was also found to be significantly negative (Table 4). However, the breeding value for fat yield was almost the same in Lysine/Lysine homozygotes and Lysine/Alanine heterozygotes, and the protein yield was not significantly higher in the 
Table 2

The breeding values $\pm \mathrm{s}_{\mathrm{x}}$ according to DGAT1 alleles $L$ and $A$ in German Holstein sires born in 1998-2001 (Mittlere Zuchtwerte $\pm \mathrm{s}_{\mathrm{x}}$ von HF-Bullen des Geburtsjahrganges 1998-2001 in Abhängigkeit vom DGAT1 Allel $L$ und $A$ )

\begin{tabular}{|c|c|c|c|c|}
\hline & & \multicolumn{2}{|c|}{ Allele } & \multirow{3}{*}{$F$} \\
\hline & & $D G A T 1^{K}$ & DGAT1 $^{\mathrm{A}}$ & \\
\hline & & $\mathrm{n}=146$ & $n=254$ & \\
\hline Milk & (kg) & $397 \pm 47$ & $708 \pm 35$ & $28.370^{* * *}$ \\
\hline RBVM & & $106 \pm 1$ & $109 \pm 1$ & $6.500^{*}$ \\
\hline Fat & (kg) & $25.7 \pm 1.8$ & $18.1 \pm 1.4$ & $11.135^{* * *}$ \\
\hline Protein & (kg) & $14.6 \pm 1.5$ & $22.5 \pm 1.1$ & $18.492^{* * *}$ \\
\hline Fat & $(\%)$ & $0.12 \pm 0.02$ & $-0.11 \pm 0.02$ & $81.536^{* * *}$ \\
\hline Protein & (\%) & $0.01 \pm 0.01$ & $-0.02 \pm 0.01$ & $8.893^{* *}$ \\
\hline
\end{tabular}

Table 3

Breeding values $\pm \mathrm{s}_{\mathrm{x}}$ of German Holstein sires born in 1993 according to their genotype on the DGAT1 locus (Mittlere Zuchtwerte $\pm \mathrm{s}_{\mathrm{x}}$ von HF-Bullen des Geburtsjahrganges 1993 in Abhängigkeit vom Genotyp am DGAT1 Lokus)

\begin{tabular}{|c|c|c|c|c|c|}
\hline & & \multicolumn{3}{|c|}{ Genotype } & \multirow{3}{*}{$F$} \\
\hline & & $D G A T 1^{K} / D G A T 1^{K}$ & $D G A T 1^{K} / D G A T 1^{A}$ & $D G A T 1^{A} / D G A T 1^{A}$ & \\
\hline & & $\mathrm{n}=10$ & $n=33$ & $n=23$ & \\
\hline Milk & (kg) & $71^{\mathrm{a}} \pm 783$ & $525^{\mathrm{b}} \pm 561$ & $588^{\mathrm{b}} \pm 514$ & 2.962 \\
\hline RBVM & & $101 \pm 14$ & $102^{\mathrm{A}} \pm 12$ & $93^{\mathrm{B}} \pm 9$ & $4.468^{*}$ \\
\hline Fat & $(\mathrm{kg})$ & $24.0^{\mathrm{a}} \pm 30.3$ & $23.8^{\mathrm{A}} \pm 25.3$ & $3.9^{\mathrm{Bb}} \pm 15.4$ & $5.537^{* *}$ \\
\hline Protein & (kg) & $6.8 \pm 20.0$ & $14.9 \pm 15.8$ & $9.3 \pm 13.2$ & 1.435 \\
\hline Fat & (\%) & $0.29^{A \mathrm{~A}} \pm 0.31$ & $0.02^{\underline{A B}} \pm 0.20$ & $-0.25^{\underline{B}} \pm 0.18$ & $25.175^{* * *}$ \\
\hline Protein & $(\%)$ & $0.07^{A \mathrm{~A}} \pm 0.16$ & $-0.03^{\mathrm{Ab}} \pm 0.11$ & $-0.13^{\underline{B} \mathrm{~B}} \pm 0.10$ & $11.204^{* * *}$ \\
\hline $\begin{array}{ll}* & P<0.05 \\
* * & P<0.01 \\
* * * & P<0.00\end{array}$ & & $\begin{array}{l}{ }^{\mathrm{a}, \mathrm{b}} \text { means with differen } \\
\mathrm{A}, \mathrm{B} \text { means with differen } \\
\underline{A}, \underline{B} \text { means with differen }\end{array}$ & $\begin{array}{l}\text { s differ significantly }(P< \\
\text { s differ significantly }(P<0 \\
\text { s differ significantly }(P<0\end{array}$ & & \\
\hline
\end{tabular}

Table 4

The breeding values $\pm \mathrm{s}_{\mathrm{x}}$ according to DGAT1 alleles $L$ and $A$ in German Holstein sires born in 1993 (Mittlere Zuchtwerte $\pm \mathrm{S}_{\mathrm{x}}$ von HF-Bullen des Geburtsjahrganges 1993 in Abhängigkeit vom DGAT1 Allel $L$ und $A$ )

\begin{tabular}{|c|c|c|c|c|}
\hline & & \multicolumn{2}{|c|}{ Allele } & \multirow{3}{*}{$F$} \\
\hline & & $D G A T 1^{K}$ & $D G A T 1^{A}$ & \\
\hline & & $n=53$ & $n=79$ & \\
\hline Milk & (kg) & $354 \pm 675$ & $562 \pm 528$ & $3.935^{*}$ \\
\hline RBVM & & $102 \pm 13$ & $97 \pm 11$ & $5.468^{*}$ \\
\hline Fat & (kg) & $23.9 \pm 26.7$ & $12.2 \pm 22.2$ & $7.438^{* *}$ \\
\hline Protein & (kg) & $11.8 \pm 17.5$ & $11.7 \pm 14.4$ & 0.004 \\
\hline Fat & (\%) & $0.13 \pm 0.28$ & $-0.14 \pm 0.23$ & $35.205^{* * *}$ \\
\hline Protein & $(\%)$ & $0.01 \pm 0.14$ & $-0.09 \pm 0.11$ & $18.705^{* * *}$ \\
\hline
\end{tabular}

$D G A T 1^{A} / D G A T 1^{A}$ genotypes than in the $D G A T 1^{K} / D G A T 1^{K}$. The highest breeding value was found in heterozygous sires. This produced the lowest Relative Breeding 
Value Milk in the Alanine homozygous sires. The number of sires born in 1993 was rather low, therefore, the effects could be estimated only roughly. Also the high standard deviations indicate the necessity to draw conclusions carefully in the older group.

\section{Discussion}

Because there was in both old and young sires a high breeding value for milk yield and a negative value for fat content in the homozygotes for the Alanine variant, the DGAT1 polymorphism may contribute to the negative correlations between the traits, similarly but more weakly for the protein content. THALLER et al. (2003) also refer to this. It is also in accordance with SPELMAN et al. (2002), where the polymorphism increased milk fat, and decreased milk protein yield and milk volume in the breeds analysed by them. Also GRISART et al. (2002) confirm the major effect of the K232A substitution in the DGAT1 gene on the milk fat content and other milk characteristics. Our findings on the positive influence of the $D G A T 1^{K}$ variant on fat yield correspond with WINTER et al. (2002). PAREEK et al. (2005) did not find significant differences among genotypes evaluating breeding values for milk performance traits in Polish Black and White sires, but they explain it by the low number of sires in the analysis.

Comparing age groups in the analysis, a certain similarity of divergences among genotypes has been observed. Nevertheless, there are some differences. The divergence between Alanine and Lysine homozygotes in the fat percentage is in the older sires group -0.54 , and in the younger one slightly less at -0.42 . This may be as a consequence of the selection in other loci influencing the character, which has bettered the fat content also in Alanine carrying animals. Therefore, the difference in the fat yield breeding value of Lysine/Lysine sires compared to the Alanine/Alanine genotypes has been in the younger group smaller (13.7) than in the older one (20.1), also in consequence of the increasing breeding value for milk yield of Alanine/Alanine sires, the difference in the Alanine homozygotes was $555 \mathrm{~kg}$ in young, and 517 in old sires, respectively.

The most outstanding differences between years were found in the breeding values of the protein content and protein yield. In the protein percentage, the difference between the $D G A T 1^{K} / D G A T 1^{K}$ and $D G A T 1^{A} / D G A T 1^{A}$ genotypes amounted, in older sires, to 0.2 in the Lysine carrying genotypes; in the younger group it was 0.05, i.e. four time less. In the protein yield breeding value, the Alanine homozygous old sires exceeded their Lysine contemporaries by $2.5 \mathrm{~kg}$, the young sires by $14.1 \mathrm{~kg}$, as mentioned above, i.e. the difference increased 5.6 times. This is a consequence of the lesser negative breeding value for protein percentage, and the moderately higher breeding value for milk in young Alanine sires compared to the older group. Here, the emphasis on protein yield in the selection has been reflected.

Comparing the divergences among breeding values for different alleles in old and young sires, the association of the $D G A T 1^{A}$ allele and a negative breeding value for the protein percentage decreased, as in the Alanine homozygous genotype, the breeding value of milk yield of the Alanine encoding allele increased. Consequently, the difference in breeding value for the protein yield in the $D G A T 1^{A}$ allele increased in the young sires. The influence of the $D G A T 1^{K}$ allele on the fat percentage did not change; the difference in fat yield decreased over time. The RBVM changed in the DGAT1 ${ }^{A}$ allele due to the higher protein yield. 
To interpret the changes correctly, it is important to take into account also the frequencies of genotypes and alleles (Fig. 2). According to the $\chi^{2}$ test (data not shown), all the changes between years have been non significant, but there has been a trend towards increasing allele $D G A T 1^{A}$ and of $D G A T 1^{A} / D G A T 1^{A}$ homozygotes in the young sires at the expense of heterozygotes.

Although the evaluation of allelic frequencies is not the goal of this paper, it is worth referring to it briefly. KAUPE et al. (2004) have found in the German Black Pied gene resource population, a frequency of the $D G A T 1^{K}$ allele of 0.01 , and in the British Frisian of 0.03 , so they conclude that the founder of both breeds, i.e. Friesian and Jutland black and white cattle, probably did not carry the allele. The frequency in today's German Holstein was found by them to be 0.42 , because the population has been male-upgraded by American and Canadian Holstein sires for 35 years.

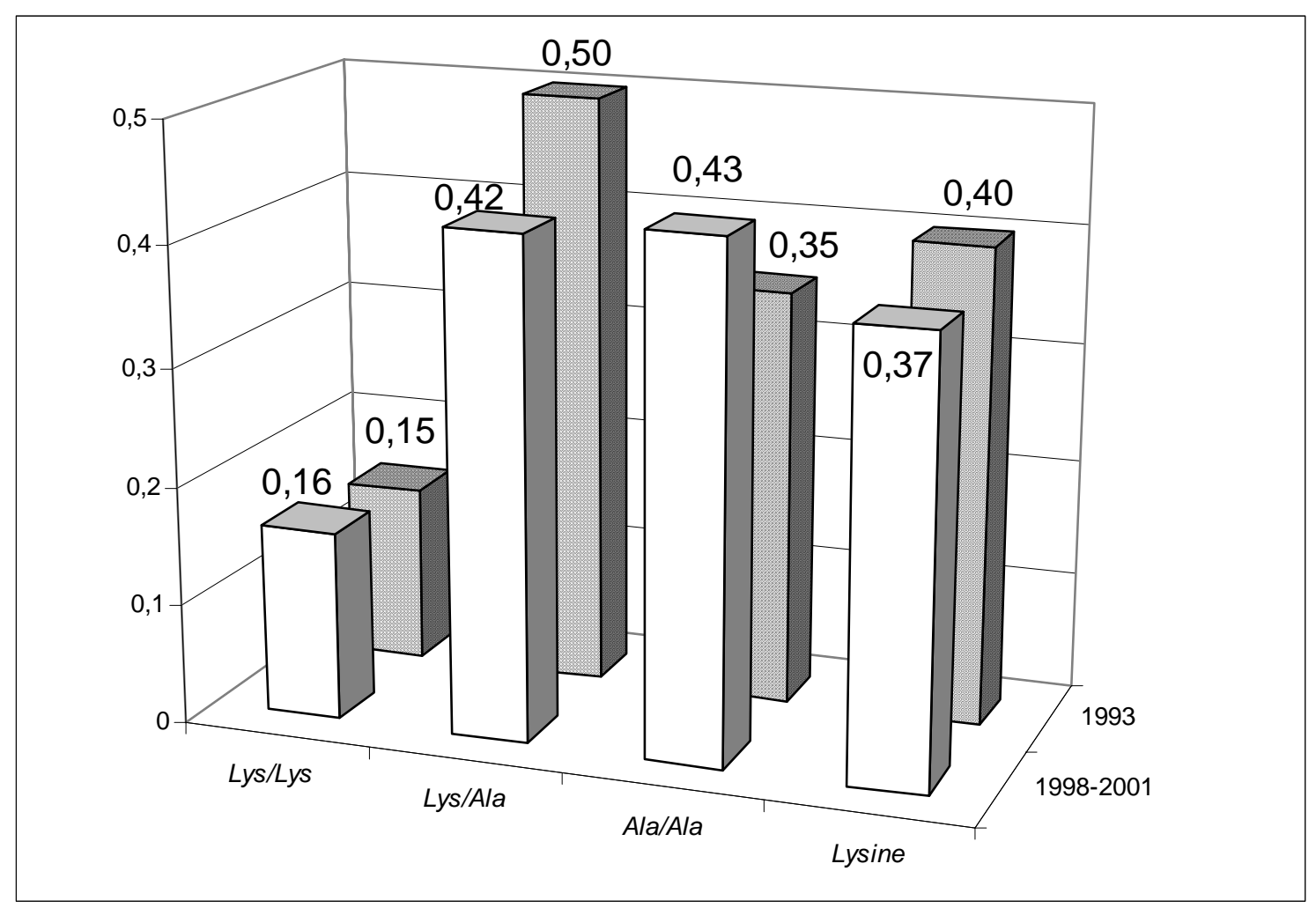

Fig. 2: The frequencies of genotypes and alleles (Genotyp- und Allelfrequenzen)

They suppose that the introgression of the allele DGAT1 ${ }^{K}$ into the North American Holstein might have occurred during its formative years through crossing with the Jersey breed. Afterwards, the frequency rose by selection, since from the 50s' milk fat has been prefered. THALLER et al. (2003) give the frequency of the allelic variant coding for Lysine in the German Holstein of 0.548; similarly PAREEK et al. (2005) found in young sires of Polish Black and White cattle, traditionally upgraded with the American Holstein breed, a frequency of the allele $D G A T 1^{K}$ of 0.68 , in sires in artificial insemination of 0.60 , and in cows of 0.48 ; rather more than in our groups. By contrast, WELLER et al. (2003) in Israeli Holstein cows give a frequency of 0.09, in sires of 0.16 .

Our results demonstrate that the genetic background against which the effect of DGAT1 is evaluated has changed somewhat in time. The effective selection on 
breeding value for protein yield affecting other loci than DGAT1 is apparent; it has increased the prevalence of $D G A T 1^{A} / D G A T 1^{A}$ genotypes in protein and milk yield, and in relative breeding value milk. It is possible that the breeding value for fat content was bettered in the younger sires homozygous for Alanine due to the selection on other loci, but the difference between years was too slight, so this is an hypothesis that must be tested by further research. According to the non significant $\chi^{2}$ test among theoretical and experiential genotypic frequencies, both old and young groups have been in Hardy-Weinberg equilibrium. That means that, along with the non significant changes in the frequencies of genotypes and alleles between years, the selection on breeding value for protein yield did not essentially affect frequencies on the amino acid position 232 Lysin - Alanin of the locus of DGAT1, although the $D G A T 1^{A} / D G A T 1^{A}$ genotype was found to be significantly better in the main selection criterion. The reason may be seen in the moderate selection on the fat yield coupled with selection on the protein in the breeding programme, which could keep the frequencies stable; and also in the fact that the DGAT1 itself does not directly influence the protein synthesis. However, it will be of interest to monitor the frequencies, as a certain tendency in the allele $D G A T 1^{A}$ has been observed. Because the breeding value for fat percentage of heterozygous sires lies within the values of homozygotes both in old and in young sires, the intermediary heredity on the locus could be assumed. The difference among old sires from intermediary heredity in protein and fat yield could not be considered important in the context, as their number was lower $(n=66)$, and of them, 33 were heterozygotes. Furthemore, the reason may also be due to female partners. By contrast to the younger group, the older sires born in 1993 were mated with Black and White cows (Schwarzbuntes Milchrind, SMR) with 25\% Jersey. As the rate of alleles encoding Lysine and Alanine in Jersey is 70:30 (THALLER et al., 2002), a higher frequency of $D G A T^{K}$ in these females is predictable. Also the possible differences on other loci could evoke other gene interference. Likewise WELLER et al. (2003) consider the effect of the locus to be approximately codominant. Nevertheless, we call attention again to the low number sires on the old group in this paper, so the next research of the chromosomal region is desired.

Summarising the results, the Lysine variant has effected the higher breeding value of fat content and yield, and the Alanine variant of milk and protein yield. Comparing the sires born in 1993 and 1998 - 2001, the selection on milk production traits in German Holstein population has changed the genetic background. The allelic and genotypic frequencies on the DGAT1 locus were not affected significantly, but a certain tendency has been observed. The intermediary heredity on the locus has been assumed. The present results are in accordance with those of THALLER et al. (2003), SPELMAN et al. (2002), GRISART et al. (2002), WINTER et al. (2002), and WELLER et al. (2003). Based on the paper and repeated results of other authors, the locus of DGAT1 is of great significance in breeding. Of course, after the polymorphism influencing performance has been revealed, and the respective molecular test is available, the main problem is to set the economic weights of particular milk production traits, and to design an effective breeding scheme accordingly.

Acknowledgements

The work was supported by Ministry of Education of the Czech Republic, project MSM 60076658/06, and by GACR, project 523/03/H076. 


\section{References}

ASHWELL, M.S.; REXROAD, C.E.; MILLER, R.H.; VAN RADEN, P.M.:

Mapping economic trait loci for somatic cell score in Holstein cattle using microsatellite markers and selective genotyping. Anim. Genet., 27 (1996), 235-242

BENNEWITZ, J.; REINSCH, N.; PAUL, S.; LOOFT, C.; KAUPE, B.; WEIMANN, C.; ERHARDT, G.;

THALLER, G.; KUHN, C.; SCHWERIN, M.; THOMSEN, H.; REINHARDT, F.; REENTS, R.; KALM, E.:

The DGAT1 K232A mutation is not solely responsible for the milk production quantitative trait locus on the bovine chromosome 14. J. Dairy Sci., 87 (2004) 2, 431-442

BUITKAMP, J.; GÖTZ, K.-U.:

Use of milk samples from a milk evaluation program fort be genotyping of cows. Arch. Tierz., Dummerstorf 47 (2004), 15-26

DYBUS, A.; SZATKOWSKA, I.; CZERNIAWSKA-PIATKOWSKA, E.; GREZSIAK, W.; WOJCIK, J.; RZEWUCKA, E.; ZYCH, S.:

PIT1-HinfI gene polymorphism and its associations with milk production traits in polish Black- and White cattle. Arch. Tierz., Dummerstorf 47 (2004), 557-563

FREYER, G.; VUKASINOVIC, N.:

Comparison of granddaughter design and general pedigree design analysis of QTL in dairy cattle: a simulation study. Czech J. Anim. Sci., 50 (2005), 545-552

FREYER, G.; KÜHN, CH.; WEIKHARDT, R.:

Comparison of different statistical-genetic appproaches of QTL detection by evaluatig reults from a real dairy cattle data set. Arch. Tierz., Dummerstorf 46 (2003), 413-423

FRIES, R., THALLER, R:

Gen für Milchleistungsmerkmale entdeckt. Milchrind, 2 (2002), 38 -39.

GEMMELL, N.J., AKIYAMA, S.:

An efficient method for the extraction of DNA from vertebrate tissues. Trends Genet., 1 (1996) 2, 338339

GRISART, B.; FARNIR, F.; KARIM, L.; CAMBISANO, N.; KIM, J.J.; KVASZ, A.; MNI, M.; SIMON, P.:

FRERE, J.M.; COPPIETERS, W.; GEORGES M:

Genetic and functional confirmation of the causality of the DGAT1 K232A quantitative trait nucleotide in affecting milk yield and composition. PNAS, 101 (2004) 8, 2398-2403

GRISART, B.; COPPIETERS, W.; FARNIR, F.; KARIM, L.; FORD, C.; BERZI, P.; CAMBISANO, N.; MNI,

M.; REID, S.; SIMON, P.; SPELMAN, R.; GEORGES, M.; SNELL, R.: Positional candidate cloning of a QTL in dairy cattle: Identification of a missense mutation in the bovine DGAT1 gene with major effect on milk yield and composition. Gen Res, 12 (2002) 2, 222-231

HARDER, B.; BENNEWITZ, J.; REINSCH, N.; THALLER, G.; THOMSEN, H.; KÜHN, C.; SCHWERIN, M.; ERHARDT, G.; FÖRSTER, M.; REINHARDT, F.; KALM, E.:

Mapping of quantitative trait loci for lactation persistency traits in German Holstein dairy cattle. J.

KALM, E.: Anim. Breed. Genet., 123 (2006), 89-96

KAWASAKI, E.S.:

Genomanalyse beim Rind. Arch. Tierz., Dummerstorf 40 (1997) Special Issue, 74-79

Sample preparation from blood, cells, and other fluids. PCR Protocols: A Guide to Methods and Applications, Academic Press, New York, 146-152, 1990

KAUPE, B.; WINTER, A.; FRIES, R.; ERHARDT, G.:

DGAT1 polymorphism in Bos indicus and Bos taurus cattle breeds. J. Dairy Res., 71 (2004), 182-187

KUCEROVA, J.; MATEJICEK, A.; JANDUROVA, O.M.; SORENSEN, P.; NEMCOVA, E.; STIPKOVA, M.;

KOTT, T.; BOUSKA, J.; FRELICH, J.:

Milk protein genes CSN1S1, CSN2, CSN3, LGB and their relation to genetic values of milk production parameters in Czech Fleckvieh. Czech J. Anim. Sci., 51 (2006), 241-247

KOVACS, K.; VÖLGYI-CSIK, J.; ZSOLNAI, A.; GYRÖRKÖS, I.,:

Associations between the Alul polymorphism of growth hormone gene and production and reproduction traits in a Hungarian Holstein-Friesian bull dam population. Arch. Tierz., Dummerstorf 49 (2006), 236249

KÜHN, C.; THALLER, G.; WINTER, A.; BININDA-EDMONDS, O.R.P.; KAUPE, B.; ERHARDT, G.;

BENNEWITZ, J.; SCHWERIN, M.; FRIES, R.:

Evidence for Multiple Alleles at the DGAT1 Locus Better Explains a Quantitative Trait Locus With Major Effect on Milk Fat Content in Cattle. Genetics, 167 (2004), 1873-1881

LIU, Z.; REINHARDT, F.; REENTS, R.:

Estimating parameters of a random regression test day model for first three lactation milk production traits using the covariance function approach. INTERBULL Bulletin No. 25 (2000a), 74-80

LIU, Z.; REINHARDT, F.; REENTS, R.: 
Parameter estimates of a random regression test day model for first three lactations somatic cell scores. INTERBULL Bulletin No. 26 (2000b), 61-65

LUDWIG, E.H.; MAHELY, R.W.; PALAOGLU, E.; ÖZBAYRAKCI, S.; PALESTRA, M.E.; BORECKI, I.B.; INNERARITY, T.L.; FARESE, R.V.JR.:

DGAT1 promoter polymorphism associated with alternations in body mass index, high density lipoprotein levels and blood pressure in Turkish women. Clinical Genetics, 62 (2002), 68-73

PAREEK, C.S.; CZARNIK, U.; ZABOLEWICZ, T.; PAREEK, R.S.; WALAWSKI, K.:

DGAT1 K232A quantitative trait nucleotide polymorphism in Polish Black-and-White cattle. J. Appl. Genet., 46 (2005) 1, 58-87

SCHWERIN, M.:

Die funktionelle Genomanalyse - neue Mőglichkeiten für Tierzucht und Tierhaltung. Arch. Tierz., Dummerstorf 47 (2004) Special Issue, 98-93

SPELMAN, R.J.; FORD, C.A.; MCELHINNEY, P.; GREGORY, G.C.; SNELL, R.G.:

Characterization of the DGAT1 gene in New Zealand dairy population. J. Dairy Sci., 85 (2002) 12, 3514-3517

THALLER, G.; KRAMER, W.; WINTER, A.; KAUPE, B.; ERHARDT, G.; FRIES, R.:

Effects of DGAT1 variants on milk production traits in German cattle breeds. J. Anim. Sci., 81 (2003) 8, 1911-1918

WELLER, J.I.; GOLIK, M.; SEROUSSI, E.; EZRA, E.; RON, M.:

Population-wide analysis of a QTL affecting milk-fat production in the Israeli Holstein population. J. Dairy Sci., 86 (2003) 6, 2219-2227

WINTER, A.; KRÄMER, W.; WERNER, F.A.O.; KOLLERS, S., KATA, S.; DURSTEWITZ, G.; BUITKAMP, J.; WOMACK, J.E.; THALLER, G.; FRIES, R.:

Association of lysine232 alaline polymorphism in bovine gene encoding acylCoA:diacylglycerol acyltransferase (DGAT1) with variation at a quantitative trait locus for milk fat content. PNAS, 99 (2002) 14, $9300-9305$

WINTER, A.; ALZINGER, A.; FRIES, R.:

Assessment of the gene content of the chromosomal regions flanking bovine DGAT1. Genomics, 83 (2004) 1, 172-180

XU, N.; PAUL, S.; BENNEWITZ, J.; REINSCH, N.; THALLER, G.; REINHARDT, F.; KÜHN, C.;

SCHWERIN, M.; ERHARD, G.; WEIMANN, C.; THOMSEN, H.; MISHRA, S.; KALM, E.:

Confirmation of quantitative trait loci for somatic cell score on bovine chromosome 18 in the German Holstein. Arch. Tierz., Dummerstorf 49 (2006), 111-119

Received: 2006-06-27

Accepted: 2006-12-06

Author's adresses

Doc. Dipl. Ing. JINDRICH CITEK*, CSc.; Prof. Dipl. Ing. VACLAV REHOUT, CSc.;

Dipl. Ing. EVA HRADECKA, Ph.D.; Dipl. Ing. LIBOR VECEREK

University of South Bohemia, Faculty of Agriculture, Studentska 13

37005 CESKE BUDEJOVICE, CZECH REPUBLIC

*Corresponding Author

E-Mail: citek@zf.jcu.cz

Prof. Dr. habil. LOTHAR PANICKE

Forschungsinstitut für die Biologie landwirtschaftlicher Nutztiere ( FBN )

Wilhelm-Stahl-Allee 2

18196 DUMMERSTORF, GERMANY

E-Mail:panicke@fbn-dummerstorf.de 